\title{
Magnesium-limited Growth of Bacillus subtilis, in Pure and Mixed Cultures, in a Chemostat
}

\author{
By D. W. TEMPEST, J. W. DICKS AND J. L. MEERS \\ Microbiological Research Establishment, Porton, Salisbury, Wiltshire
}

(Accepted for publication 26 April 1967)

\begin{abstract}
SUMMAR Y
The influence of $\mathrm{Mg}^{2+}$-limitation on the growth of a typical Gram-positive organism-Bacillus subtilis-was investigated and the data compared with that obtained with Aerobacter aerogenes grown under similar conditions. The magnesium contents of both organisms varied with growth rate but were very similar at corresponding growth rates. With $\mathrm{Mg}^{2+}$-limited chemostat cultures of each organism, uptake of $\mathrm{Mg}^{2+}$ was almost complete at specific growth rates less than $0.7 \times$ maximum. Cellular $\mathrm{Mg}^{2+}$ was tightly bound, none being removed by suspension of the organisms at $20^{\circ}$ in $0.85 \%(\mathrm{w} / \mathrm{v}) \mathrm{NaCl}$. When $\mathrm{Mg}^{2+}$-limited organisms were suspended in environments containing $\mathrm{Mg}^{2+}$, this ion was rapidly adsorbed; the amount adsorbed varied with both the initial extracellular $\mathrm{Mg}^{2+}$ concentration and the composition of the diluent. $B$. subtilis had a greater capacity for $\mathrm{Mg}^{2+}$ adsorption than $A$. aerogenes but its affinity for this ion was less. The latter difference correlated with the ability of $A$. aerogenes to outgrow $B$. subtilis rapidly in $\mathrm{Mg}^{2+}$-limited chemostat cultures containing both organisms. The significance of these results is discussed in relation to the reports from other laboratories concerning differences between Gram-positive and Gram-negative bacteria in $\mathrm{Mg}^{2+}$ content, uptake of $\mathrm{Mg}^{2+}$ and ability to grow in media of low $\mathrm{Mg}^{2+}$ content.
\end{abstract}

\section{INTRODUCTION}

It has been reported by Webb (1949) and by Rouf (1964) that the magnesium contents of Gram-positive bacilli (Bacillus subtilis, B. cereus) are much greater than those of Gram-negative organisms (Aerobacter aerogenes, Escherichia coli). Furthermore, Webb (1966) concluded that, unlike the Gram-negative organisms, bacilli (B. megaterium and B. mesentericus, as well as B. subtilis) would not grow in simple salts media containing less than $\mathrm{I}-2 \mu \mathrm{g}$. $\mathrm{Mg}^{2+} / \mathrm{ml}$. Recently the magnesium content of $A$. aerogenes has been found to be a function of the growth rate and to be related to the bacterial RNA content (Tempest \& Strange, I966; Tempest, Dicks \& Hunter, I966; Dicks \& Tempest, 1966). Since the RNA contents of A. aerogenes and B. megaterium do not differ significantly when grown under similar conditions (Herbert, 1958), the apparent gross difference in magnesium requirement, and content, is of considerable interest and possible importance. It follows from the observations of Tempest \& Strange (1966), and of Dicks \& Tempest (1966), that a meaningful comparison of the magnesium contents of Gram-positive and Gram-negative organisms can be made only if they are grown under nearly identical conditions-particularly with regard to temperature and growth rate. Furthermore, because a variable amount of magnesium may be loosely bound to the walls of bacteria grown in media con- 
taining an excess of this cation, it is preferable to compare organisms that have been grown in a $\mathrm{Mg}^{2+}$-limited environment since these contain no detectable adsorbed magnesium (Tempest \& Strange, 1966). Alternatively, adsorbed magnesium can be removed by washing organisms in $0.85 \%(w / v) ~ N a C l$ (Strange \& Shon, 1964). This paper compares the magnesium contents of $\mathrm{Mg}^{2+}$-limited $B$. subtilis and A. aerogenes grown at corresponding rates, at $35^{\circ}$; no significant differences were found. However, differences were observed in the abilities of the organisms to adsorb $\mathrm{Mg}^{2+}$ when suspended in various environments, and these findings correlated with the behaviour of the organisms in $\mathrm{Mg}^{2+}$-limited mixed cultures. It is concluded that the saturation constants $\left(K\right.$, values) for $\mathrm{Mg}^{2+}$ of $B$. subtilis and $A$. aerogenes organisms differ substantially. A preliminary report on our findings has been published (Tempest, Dicks \& Meers, 1967).

\section{METHODS}

Organisms: Bacillus subtilis var. niger (obtained from Fort Detrick, Md., U.S.A., originally called Bacillus globigii; strain ATCC 9372 is considered to be from the same source) was maintained by monthly subculture on tryptic meat digest agar slopes containing $0.2 \%(\mathrm{w} / \mathrm{v})$ glucose; B. megaterium KM (obtained from Dr J. F. Wilkinson) was maintained on tryptic meat digest agar containing $0.2(\mathrm{w} / \mathrm{v})$ mannitol; Aerobacter aerogenes (NCTC418) was maintained on tryptic meat digest agar slopes; Torula utilis (NCYC 32I) was maintained on yeast extract, peptone, glucose agar slopes.

Growth conditions. Continuous cultures of organisms were maintained in 0.51 . chemostats of the type described by Herbert, Phipps \& Tempest (1965). The temperature was controlled at $35^{\circ}$; the $\mathrm{pH}$ value was regulated at 6.5 and $7 \cdot 0$, respectively, for the Aerobacter aerogenes and Bacillus subtilis cultures. The growth medium, which was limited with respect to its $\mathrm{Mg}^{2+}$ content, had the following composition: $\mathrm{Na}_{2} \mathrm{HPO}_{4}$, $5.0 \times 10^{-3} \mathrm{M} ; \mathrm{NH}_{4} \mathrm{H}_{2} \mathrm{PO}_{4}, 4.5 \times 10^{-2} \mathrm{M} ;\left(\mathrm{NH}_{4}\right)_{2} \mathrm{SO}_{4}, 2.5 \times 10^{-2} \mathrm{M} ; \mathrm{K}_{2} \mathrm{SO}_{4}, 3.0 \times 10^{-3} \mathrm{M}$; citric acid, $\mathrm{I} \cdot 0 \times \mathrm{IO}^{-3} \mathrm{M} ; \mathrm{MgCl}_{2}, 2.5 \times 10^{-4} \mathrm{M} ; \mathrm{CaCl}_{2}$ and $\mathrm{FeCl}_{3}$, each $\mathrm{I} \cdot 0 \times 10^{-4} \mathrm{M}$; $\mathrm{MnCl}_{2}$ and $\mathrm{ZnCl}_{2}$, each $2.5 \times 10^{-5} \mathrm{M} ; \mathrm{CuCl}_{2}, \mathrm{CoCl}_{2}$ and $\mathrm{Na}_{2} \mathrm{MoO}_{4}$ each $5 \times \mathrm{IO}^{-6} \mathrm{M}$; a sterile glucose solution, in water, was added to a final concentration of $30 \mathrm{~g}$. glucose $/ 1$. after sterilization ( $121^{\circ}, 30 \mathrm{~min}$.) of the bulk medium. Batch cultures were grown in a similar medium, differing only in the $\mathrm{Mg}^{2+}$ concentration.

Analytical procedures. Culture bacterial concentrations (equiv. mg. dried bacteria/ $\mathrm{ml}$. culture) and the macromolecular compositions of organisms were determined by methods described previously (Tempest, Hunter \& Sykes, 1965). Bacterial magnesium contents were determined by atomic absorption (using an EEL Model 140 Spectrophotometer) on $\mathrm{HClO}_{4}$ extracts, prepared as described by Tempest \& Strange (1966).

Mixed culture experiments. Cultures of Bacillus subtilis, Aerobacter aerogenes and Torula utilis were grown in 0.251 . chemostats (designed by Dr D. Herbert) without pH control. The growth medium was as follows: $\mathrm{Na}_{2} \mathrm{HPO}_{4}, 2.5 \times 10^{-2} \mathrm{M} ; \mathrm{NH}_{4} \mathrm{H}_{2} \mathrm{PO}_{4}$, $3.75 \times 10^{-2} \mathrm{M} ; \mathrm{K}_{2} \mathrm{SO}_{4}, 2.0 \times 10^{-3} \mathrm{M}$; citric acid, $5.0 \times 10^{-4} \mathrm{M} ; \mathrm{MgCl}_{2}, 3.75 \times 10^{-5} \mathrm{M}$; $\mathrm{CaCl}_{2}$ and $\mathrm{FeCl}_{3}$, each $2.5 \times 10^{-5} \mathrm{M}$; trace amounts of $\mathrm{Mn}^{2+}, \mathrm{Cu}^{2+}, \mathrm{Co}^{2+}, \mathrm{Zn}^{2+}$ and $\mathrm{Na}_{2} \mathrm{MoO}_{4}$; glucose to a final concentration of $10 \mathrm{~g}$./1. The $\mathrm{pH}$ value was adjusted to 6.4 before sterilization; after sterilization (autoclaving at $12 \mathrm{I}^{\circ}$ for $30 \mathrm{~min}$.) the $\mathrm{pH}$ value was $6 \cdot 5-6 \cdot 6$. Continuous cultures of each organism were established, in separate chemostats, at a dilution rate of $0.3 \mathrm{hr}^{-1}$ and with the temperature regulated at $33^{\circ}$. The steady-state $\mathrm{pH}$ values were found to be $6.4,6.3$ and 5.5 , respectively, for 
cultures of $B$. subtilis, $T$. utilis and $A$. aerogenes. Mixed cultures were produced by pipetting small volumes ( $1.0 \mathrm{ml}$. unless stated otherwise) from one chemostat culture into another chemostat culture. The flow rates were maintained at $0.3 \mathrm{hr}^{-1}$ and samples taken at convenient times thereafter for determination of microbial content and distribution. Total numbers of bacteria and yeast were determined by direct observation and counting, using a Thoma chamber of $0.02 \mathrm{~mm}$ depth, and phase-contrast microscopy. The proportions of $A$. aerogenes organisms in mixed cultures containing $B$. subtilis were assessed by microscopic examination of Gram-stained preparations.

\section{RESULTS}

\section{Influence of dilution rate on the yield value and macromolecular} composition of $\mathrm{Mg}^{2+}$-limited Bacillus subtilis

With $\mathrm{Mg}^{2+}$-limited chemostat cultures of Aerobacter aerogenes, the yield ( $\mathrm{g}$. bacteria formed/g. $\mathrm{Mg}^{2+}$ consumed) varied with the dilution rate (Tempest, Hunter \& Sykes, 1965). This indicated a change in cellular $\mathrm{Mg}^{2+}$ content with growth rate which

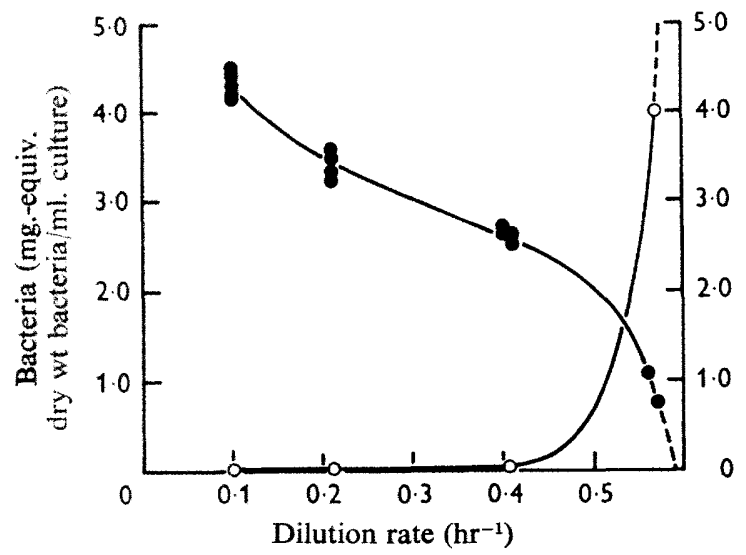

Fig. 1

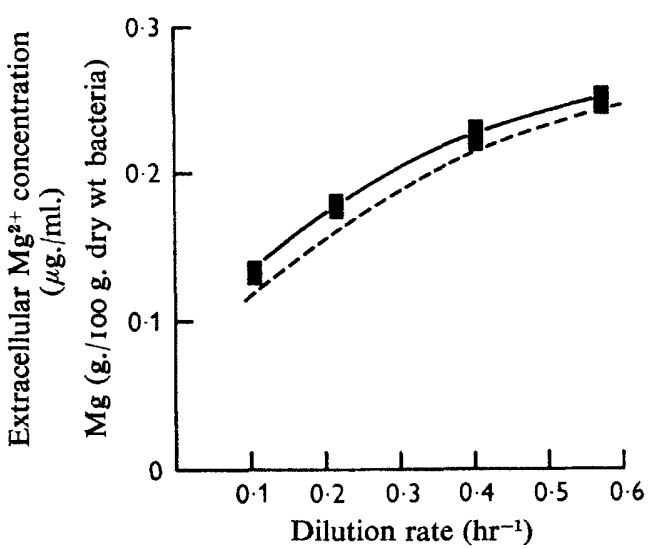

Fig. 2

Fig. I. Steady-state concentrations of Bacillus subtilis and extracellular $\mathbf{M g}^{2+}$ as functions of dilution rate $\left(35^{\circ} ; \mathrm{pH} 7.0\right)$ in a $\mathrm{Mg}^{2+}$-limited chemostat culture. Values at each dilution rate were determined over a 2 - to 3 -day period, after initial equilibration of the culture for a period of 2 days., $\mathrm{mg}$. dry wt bacteria/ml. culture; $O, \mu \mathrm{g}$. extracellular $\mathrm{Mg}^{2+} / \mathrm{ml}$. culture.

Fig. 2. The magnesium content of $\mathrm{Mg}^{2+}$-limited Bacillus subtilis and Aerobacter aerogenes as a function of growth rate. Mean magnesium content ( $\%$ of bacterial dry weight) of B. subtilis (solid line) and the corresponding magnesium content of $\mathrm{Mg}^{2+}$-limited A. aerogenes (broken line).

paralleled the change in RNA content. Figure I shows the effect of dilution rate on the steady-state concentration of Bacillus subtilis organisms in a $\mathrm{Mg}^{2+}$-limited chemostat culture. Like the $\mathrm{Mg}^{2+}$-limited $A$. aerogenes culture, bacterial concentration varied with growth rate; an increase in dilution rate caused a decrease in yield. Over $90 \%$ of the $\mathrm{Mg}^{2+}$ added to the culture was present in the organisms at all dilution rates below $0.5 \mathrm{hr}^{-1}$ (Fig. I); thus, the magnesium content of $B$. subtilis varied with the growth rate (Fig. 2). Also plotted in Fig. 2 are data on the variation in magnesium content of $A$. aerogenes (Tempest \& Strange, I966); the two sets of data are strikingly similar.

The macromolecular composition of $\mathrm{Mg}^{2+}$-limited Bacillus subtilis at various growth rates is shown in Table $\mathrm{I}$. There was a progressive increase in cellular RNA 
and carbohydrate contents with increasing growth rates, whereas the DNA and protein contents decreased or varied irregularly. An interrelationship between RNA and magnesium was suggested by the relatively constant $\mathrm{RNA} / \mathrm{Mg}^{2+}$ ratio (Table I); this was quantitatively similar to that reported with Aerobacter aerogenes (Tempest et al. I966) and with Pseudomonas fluorescens (Sykes \& Tempest, 1965).

\section{Binding of $\mathrm{Mg}^{2+}$ to Bacillus subtilis}

It was reported by Strange \& Shon (1964) that Aerobacter aerogenes organisms which had been separated from cultures containing $\mathrm{Mg}^{2+}$ in excess of the growth requirement, and which had been washed in distilled water, had an amount of $\mathrm{Mg}^{2+}$

\section{Table I. Macromolecular composition of $\mathrm{Mg}^{2+}$-limited Bacillus subtilis grown at different dilution rates}

All the data in this table are average values, obtained from at least two samples (collected and processed on different days) grown at each rate.

$\begin{array}{ccccccc}\begin{array}{c}\text { Diln } \\ \text { rate } \\ \left(\mathrm{hr}^{-1}\right)\end{array} & \begin{array}{c}\text { Dry wt } \\ \text { bacteria } \\ \text { (mg./ml. } \\ \text { culture) }\end{array} & \text { Protein } & \text { Carbohydrate } & \text { DNA } & \text { RNA } & \begin{array}{c}\text { Molar } \\ \text { ratio } \\ \text { RNA/Mg } / \mathrm{Mg}^{2+}\end{array} \\ 0.10 & 4.35 & 62.1 & 12.5 & 1.9 & 9.4 & 4.6 \\ 0.21 & 3.40 & 53.1 & 12.5 & 1.9 & 12.2 & 4.6 \\ 0.41 & 2.56 & 56.7 & 13.4 & 1.8 & 13.9 & 4.2 \\ 0.56 & 0.93 & 55.3 & 15.0 & 1.8 & 15.5 & 4.5\end{array}$

Table 2. Comparison of magnesium contents of water- and saline-washed Bacillus subtilis organisms, grown at various dilution rates $\left(35^{\circ}, \mathrm{pH} 7 \cdot \mathrm{I}\right)$

Samples of bacteria, separated from chemostat cultures, were washed with distilled water or $0.85 \%(w / v) ~ N a C l$ and extracted with $\mathrm{N}-\mathrm{HClO}_{4}$ for $\mathrm{Mg}^{2+}$ assay (see Methods).

\begin{tabular}{|c|c|c|c|}
\hline \multirow{2}{*}{$\begin{array}{c}\text { Diln rate } \\
\left(\mathrm{hr}^{-1}\right)\end{array}$} & \multicolumn{2}{|c|}{ g. $\mathrm{Mg}^{2+} / \mathrm{I} 00 \mathrm{~g}$. dry bacteria } & \multirow{2}{*}{$\begin{array}{c}\text { Ratio } \\
\text { water-washed: } \\
\text { NaCl-washed }\end{array}$} \\
\hline & Water-washed & $\mathrm{NaCl}$-washed & \\
\hline 0.10 & 0.140 & 0.140 & 1.00 \\
\hline 0.21 & 0.169 & $0 \cdot 169$ & 1.00 \\
\hline 0.21 & 0.184 & 0.188 & 0.98 \\
\hline 0.40 & 0.238 & 0.233 & 1.02 \\
\hline 0.41 & 0.212 & 0.216 & 0.98 \\
\hline 0.57 & 0.247 & 0.237 & $I \cdot 04$ \\
\hline 0.57 & 0.257 & 0.252 & $1 \cdot 02$ \\
\hline
\end{tabular}

bound loosely at their surface; this adsorbed $\mathrm{Mg}^{2+}$ could be removed by suspension of the organisms in $0.85 \%(\mathrm{w} / \mathrm{v}) \mathrm{NaCl}$ solution. $\mathrm{Mg}^{2+}$-limited $A$. aerogenes organisms were devoid of surface-bound $\mathrm{Mg}^{2+}$ (Tempest \& Strange, 1966); similarly, no significant difference was found between the magnesium contents of water- and salinewashed $\mathrm{Mg}^{2+}$-limited Bacillus subtilis organisms (Table 2). However, both $\mathrm{Mg}^{2+}$ limited $A$. aerogenes and $B$. subtilis organisms would take up $\mathrm{Mg}^{2+}$ when exposed to dilute solutions of $\mathrm{MgCl}_{2}$ for brief periods of time ( $2 \mathrm{~min}$. or less). Over $80 \%$ of this $\mathrm{Mg}^{2+}$ could be recovered from the organisms by subsequent treatment with $0.85 \%$ saline, suggesting that it was largely adsorbed. B. subtilis had a greater capacity for $\mathrm{Mg}^{2+}$ adsorption than $A$. aerogenes. Thus, with organisms grown at a dilution rate of $0.2 \mathrm{hr}^{-1}$ and washed once, in $2.5 \mathrm{~mm}-\mathrm{MgCl}_{2}$ solution, $B$. subtilis adsorbed $5.6 \mu \mathrm{g}$. 
$\mathrm{Mg}^{2+} / \mathrm{mg}$. equiv. dry bacteria whereas $A$. aerogenes adsorbed $3.6 \mu \mathrm{g}$. $\mathrm{Mg}^{2+} / \mathrm{mg}$. equiv. dry bacteria $\left(3.05 \times 10^{-15} \mathrm{~g} . \mathrm{Mg}^{2+} /\right.$ organism and $\mathrm{I} \cdot 29 \times \mathrm{IO}^{-15} \mathrm{~g} . \mathrm{Mg}^{2+} /$ organism, respectively).

The greater capacity for $\mathrm{Mg}^{2+}$ adsorption of Bacilus subtilis, compared with Aerobacter aerogenes, indicated a greater number of cation binding sites per organism (about $8 \times 10^{7}$, compared with about $3 \times 10^{7}$ ); it provided no information on strength of binding ( $\mathrm{Mg}^{2+}$-affinity) or ion specificity. This was sought by studying the adsorption of $\mathrm{Mg}^{2+}$ in the presence of a competing ion. Figure 4 shows the results of an experiment in which $\mathrm{Mg}^{2+}$-limited $A$. aerogenes and $B$. subtilis organisms were suspended (for $2 \mathrm{~min}$.) in saline containing graded concentrations of $\mathrm{Mg}^{2+}$, then washed with water and analysed for $\mathrm{Mg}^{2+}$. Although $B$. subtilis had the greater $\mathrm{Mg}^{2+}$ binding capacity at high $\mathrm{Mg}^{2+}$ concentrations, at low $\mathrm{Mg}^{2+}$ concentrations (in the presence of saline) these organisms adsorbed less $\mathrm{Mg}^{2+}$ than $A$. aerogenes organisms (Fig. 3); this indicated a difference in affinity for this cation. Similarly, the presence of growth-medium constituents, or of EDTA, markedly influenced the uptake of $\mathrm{Mg}^{2+}$ by $B$. subtilis, whereas they had substantially less effect on $\mathrm{Mg}^{2+}$ adsorption by A. aerogenes organisms (Fig. 3).

\section{Growth of Bacillus subtilis in $\mathbf{M g}^{2+-l i m i t e d ~ m i x e d ~ c u l t u r e s ~}$}

Webb (1966) concluded that Gram-positive bacilli, unlike Gram-negative organisms, were unable to utilize $\mathrm{Mg}^{2+}$ when the external concentration of this cation was low. Whereas it is clear (Fig. I) that Bacillus subtilis would grow in a chemostat under conditions where the extracellular $\mathrm{Mg}^{2+}$ concentration was $10 \%$, or less, of the minimum value reported to support the growth of other bacilli in a batch culture (see Webb (1966), his table I), the differences in $\mathrm{Mg}^{2+}$ adsorption observed between B. subtilis and Aerobacter aerogenes accorded, qualitatively, with Webb's conclusion. However, the ability of organisms to assimilate $\mathrm{Mg}^{2+}$ may not be related directly to their surface adsorption properties. Therefore mixed population experiments were carried out, in $\mathrm{Mg}^{2+}$-limited chemostat cultures, to assess the relative efficiencies of $\mathrm{Mg}^{2+}$ utilization (i.e. to compare the saturation constants for $\mathrm{Mg}^{2+}$ of the various organisms).

Mixed culture experiments were carried out as described in the Methods section and the results of these are contained in Figs 4 and 5. In each of three experiments in which $\mathrm{Mg}^{2+}-$ limited Aerobacter aerogenes organisms were added to growing $\mathrm{Mg}^{2+}$ limited Bacillus subtilis cultures (initial B. subtilis concentration, $4.5 \times 10^{8}$ organisms/ $\mathrm{ml}$; initial $A$. aerogenes concentration, less than $2 \times 10^{6}$ organisms $/ \mathrm{ml}$.), the Gramnegative organism rapidly outgrew the bacillus; after $24 \mathrm{hr}$ the $A$. aerogenes concentration had increased to $6 \cdot 7-8.5 \times 10^{8}$ organisms $/ \mathrm{ml}$. and the $B$. subtilis concentration had diminished to less than $6 \times 10^{6}$ organisms $/ \mathrm{ml}$. (Fig. 4).

Previous observations on the growth of a contaminant bacillus (probably Bacillus subtilis) in $\mathrm{K}^{+}$- and $\mathrm{Mg}^{2+}-$ limited chemostat cultures of Torula utilis suggested that bacilli may not be able to outgrow $T$. utilis in environments where growth rate is limited by the availability of $\mathrm{Mg}^{2+}$. Therefore experiments were carried out to study the growth of $B$. subtilis in mixed $\mathrm{Mg}^{2+}$-limited cultures containing $T$. utilis. When $10 \mathrm{ml}$. of a $\mathrm{Mg}^{2+-}$ limited B. subtilis culture $\left(4.5 \times 10^{8}\right.$ organisms $/ \mathrm{ml}$.) were added to $90 \mathrm{ml}$. of a similarly limited culture of $T$. utilis, containing $6 \times 10^{7}$ organisms $/ \mathrm{ml}$., the bacterial concentration in the mixed chemostat culture progressively diminished over 
$24 \mathrm{hr}$ from $5 \times 10^{7}$ organisms $/ \mathrm{ml}$. to $\mathrm{I} \times 10^{6}$ organisms $/ \mathrm{ml}$. (Fig. 5 ). However, contrary to our expectations when small amounts of $T$. utilis (equivalent, after mixing, to about $6 \times 10^{6}$ organisms $/ \mathrm{ml}$.) were added to a $\mathrm{Mg}^{2+}$-limited $\mathrm{B}$. subtilis culture $\left(4.5 \times 10^{8}\right.$ bacteria/ml.) the yeast failed to grow. Even T. utilis organisms at an initial concentration of $2.8 \times 10^{7}$ organisms $/ \mathrm{ml}$. (obtained by adding $50 \mathrm{ml}$. of yeast culture to $50 \mathrm{ml}$. of the bacterial culture) failed to outgrow the bacillus (Fig. 5). This suggested the presence, in the $\mathrm{Mg}^{2+-}$-limited $B$. subtilis culture, of either a mycostatic substance or a bacterial product which enhanced $\mathrm{Mg}^{2+}$ uptake by the bacillus. Since $T$. utilis would grow, without lag and at an undiminished rate, in a bacteria-free $\mathrm{Mg}^{2+}$-limited B. subtilis culture fluid (supplemented with $\mathrm{Mg}^{2+}$ ) it seemed unlikely that a mycostatic substance was synthesized by $B$. subtilis. Therefore the possible involvement of extracellular bacterial products in $\mathrm{Mg}^{2+}$ uptake by the bacillus was investigated.

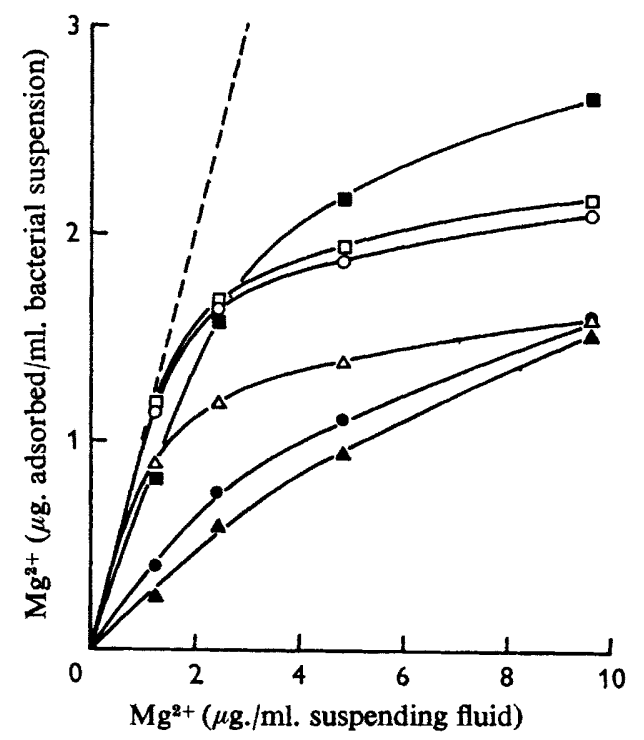

Fig. 3

Fig. 3. Adsorption of $\mathrm{Mg}^{2+}$ by Bacillus subtilis and Aerobacter aerogenes organisms. The organisms were grown at a dilution rate of $0.2 \mathrm{hr}^{-1}\left(35^{\circ} ; \mathrm{pH} 7.0\right.$ and 6.5 , respectively), centrifuged and resuspended in various solutions containing $0.05-0.50 \mathrm{mM}-\mathrm{MgCl}_{2}$. Suspensions were centrifuged (within 2 min. of mixing), the supernatant solutions discarded and the bacteria washed once with distilled water. The bacterial magnesium was extracted with I N-HClO metry. Adsorbed $\mathrm{Mg}^{2+}$ was calculated as that in excess of magnesium present in untreated organisms. $\mathbf{\square}, \square, \mathbf{M g}^{2+}$ adsorbed from solutions containing $0.85 \%(w / v) \mathrm{NaCl} ; \boldsymbol{\bullet}, 0$, $\mathrm{Mg}^{2+}$ adsorbed from solutions containing $0.85 \%(w / v) ~ \mathrm{NaCl}$ plus I $.5 \mathrm{~mm}-\mathrm{EDTA} ; \boldsymbol{\Lambda}, \triangle$, $\mathrm{Mg}^{2+}$ adsorbed from the growth medium salts solution (each containing the graded concentrations of $\mathrm{MgCl}_{2}$ as detailed above). The closed symbols refer to adsorption by B. subtilis, and the open symbols to adsorption by $A$. aerogenes. The broken line indicates $\mathrm{Mg}^{2+}$ adsorption by each organism in the absence of competing ions.

Webb (1966) had shown that addition of amino-acid mixtures to a simple basal medium increased $\mathrm{Mg}^{2+}$ uptake by Bacillus megaterium and decreased the value of the minimum $\mathrm{Mg}^{2+}$ concentration necessary for initiation of growth. When the experiment detailed in Fig. 5 was repeated using a medium modified by the addition of I \% (w/v) Casamino Acids (Difco Laboratories, Detroit, U.S.A.) plus tryptophan 
$(0.02 \%, w / v)$, the bacillus now outgrew the yeast. In subsequent experiments the initial $B$. subtilis concentration was decreased to $2 \times 10^{6}$ organisms $/ \mathrm{ml}$; the bacilli still outgrew the yeast, though requiring $48 \mathrm{hr}$ to replace the yeast completely (cf. Fig. 4).

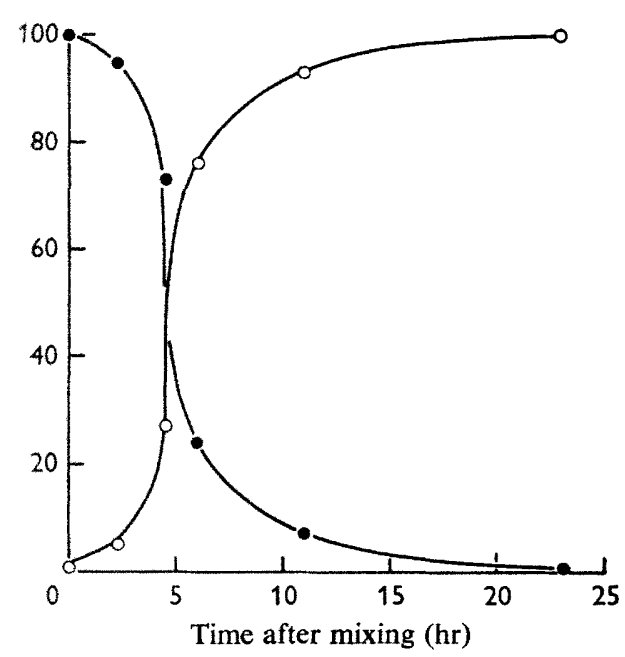

Fig. 4

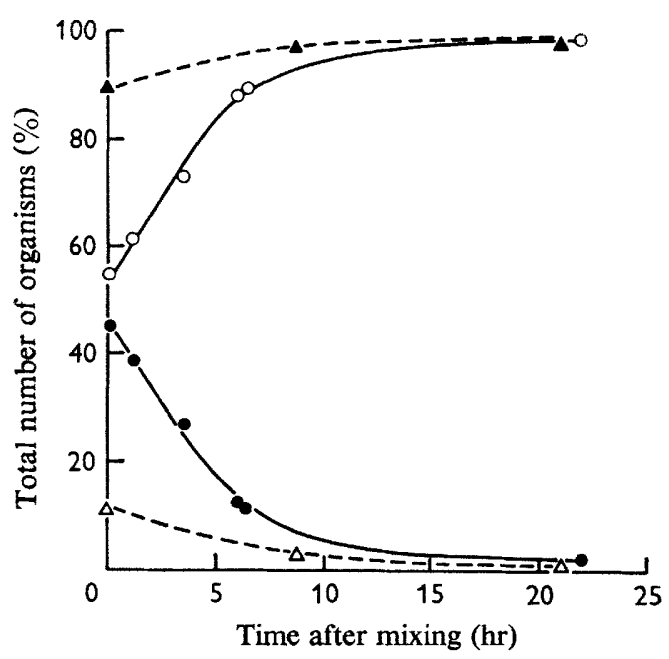

Fig. 5

Fig. 4. Growth of Bacilus subtilis (O) and Aerobacter aerogenes $(O)$ in a $\mathbf{M g}^{2+}$-limited simple salts medium in a chemostat. The initial concentration of $B$. subtilis was $4.5 \times 10^{8}$ organisms/ $\mathrm{ml}$. and of $A$. aerogenes, $2 \times 10^{6}$ organisms $/ \mathrm{ml}$. $(99.5 \%$ and $0.5 \%$, respectively, of the initial population). The dilution rate was $0.3 \mathrm{hr}^{-1}$ and the temperature $33^{\circ}$; the initial $\mathrm{pH}$ value was 6.4 but decreased to 5.5 with the progressive increase in the concentration of $A$. aerogenes organisms. Identical results were obtained when $1 \%(w / v)$ Casamino Acids was present in the medium.

Fig. 5. Growth of Bacillus subtilis and Torula utilis in a $\mathrm{Mg}^{2+-}$ limited simple salts medium in a chemostat. In the experiment represented by the solid lines, the initial concentration of B. subtilis (O) was $4.5 \times 10^{7}$ organisms $/ \mathrm{ml}$. and of $T$. utilis $(O) 5.4 \times 10^{7}$ organisms $/ \mathrm{ml}$., i.e. $45.5 \%$ and $54.5 \%$ of the initial population, respectively. Also recorded (broken lines) are the results of an experiment in which the initial concentration of $B$. subtilis was increased to $2.2 \times 10^{8}$ organisms $/ \mathrm{ml}$. (A) and that of $T$. utilis reduced to $2.8 \times 10^{7}$ organisms $/ \mathrm{ml} .(\triangle)$, i.e. $89.5 \%$ and $10.5 \%$ of the initial population, respectively. In both experiments the dilution rate was $0.3 \mathrm{hr}^{-1}$ and the temperature $33^{\circ}$. The $\mathrm{pH}$ value $(6.4)$ did not vary during the course of each experiment.

\section{DISCUSSION}

Since the $\mathrm{Mg}^{2+}$ content of bacteria may vary with growth rate-which, in a batch culture, would depend on factors such as medium composition and temperaturethen a meaningful comparison of the $\mathrm{Mg}^{2+}$ contents of various species would be possible only if the growth conditions were rigidly controlled and standardized. Clearly the differences in $\mathrm{Mg}^{2+}$ content between Gram-positive and Gram-negative organisms, reported by Webb (1949) and Rouf (1964), are of no significance, since widely different conditions were used in growing the various organisms.

The gross differences, reported by Webb (1966), between the abilities of Grampositive bacilli and Gram-negative bacteria to concentrate $\mathrm{Mg}^{2+}$ (presumably intracellularly) from simple chemically defined media are not confirmed here. Bacillus subtilis var. niger grew at steady-state $\mathrm{Mg}^{2+}$ concentrations far below the minimum values reported to be necessary for the growth of other bacilli (B. subtilis $\mathrm{F} 3$, B. subtilis MARBURG, $B$. mesentericus, $B$. megaterium). Whereas it is possible that products of 
metabolism, excreted into the medium, may have stimulated $\mathrm{Mg}^{2+}$ uptake by $\mathrm{Mg}^{2+}$ limited B. subtilis organisms, small numbers (about $5 \times 10^{6}$ organisms/ml., final concentration) of continuously grown $\mathrm{Mg}^{2+}$-limited $B$. subtilis would readily grow when inoculated into a simple salts medium containing $0.3 \mu \mathrm{g}$. $\mathrm{Mg}^{2+} / \mathrm{ml}$.; after $24 \mathrm{hr}$, more than $95 \%$ of the total $\mathrm{Mg}^{2+}$ could be recovered from the organisms whose concentration had increased to about $3 \times 10^{8}$ bacteria $/ \mathrm{ml}$.

It can be argued that, among the bacilli, Bacillus subtilis var. niger may be unique in requiring much lower concentrations of $\mathrm{Mg}^{2+}$ for growth. However, B. megaterium also would grow in a $\mathrm{Mg}^{2+}$-limited chemostat culture and take up almost all the $\mathrm{Mg}^{2+}$ from the environment at dilution rates less than $0.3 \mathrm{hr}^{-1}$. We conclude, therefore, that the observations of Webb (1966) must reflect physiological factors other than the relative ability of bacilli and Gram-negative bacteria to take up from their environment, and utilize, low concentrations of $\mathrm{Mg}^{2+}$. In this connexion the rapid death-rate of vegetative bacilli in aqueous suspension ( $\mathrm{Mr} \mathrm{R}$. E. Strange, personal communication) and the known effects of $\mathrm{Mg}^{2+}$ on the survival of micro-organisms in aqueous environments (Postgate \& Hunter, 1962, 1964; Tempest \& Strange, 1966) may be factors contributing to Webb's findings.

Despite the quantitative differences between the results reported here and those of Webb (I966), the broad conclusions are similar. In the presence of competing ions Bacillus subtilis var. niger has a demonstrably lower affinity for $\mathrm{Mg}^{2+}$ than Aerobacter aerogenes (Fig. 3) and at low extracellular $\mathrm{Mg}^{2+}$ concentrations (imposed, in the chemostat, by maintaining the dilution rate at a value substantially less than the critical rate $-D_{c}$ ) the bacillus grows more slowly than the Gram-negative organism (Fig. 4). Furthermore, the rapid rate at which $A$. aerogenes outgrew B. subtilis in the $\mathrm{Mg}^{2+}$ limited culture suggests that the respective saturation constants for $\mathrm{Mg}^{2+}$ are substantially different. In contrast, the rates of take-over of B. subtilis and Torula utilis, respectively, when inoculated together into a $\mathrm{Mg}^{2+}$-limited simple salts medium with and without amino acids, indicates that the $\mathrm{Mg}^{2+}$ saturation constants of these organisms are less different. If, in our experiments, amino acids influenced $\mathrm{Mg}^{2+}$ uptake as Webb (1966) indicated, then it is clear that they had a greater effect on $B$. subtilis than on T. utilis, since they reversed the take-over patterns in mixed culture experiments. But addition of amino acids did not influence the rate at which $A$. aerogenes outgrew $B$. subtilis in a $\mathrm{Mg}^{2+}$-limited mixed culture (Fig. 4), suggesting that these compounds have an equivalent effect on $\mathrm{Mg}^{2+}$ uptake by $A$. aerogenes and $B$. subtilis.

The authors are indebted to Dr C. E. Gordon Smith and Mr R. E. Strange for their valuable criticisms of this work and for many useful discussions. We are indebted to $\mathrm{Mr}$ T. H. Dunham for skilled technical assistance.

\section{REFERENCES}

Dicks, J, W. \& Tempest, D. W. (1966). The influence of temperature and growth rate on the quantitative relationship between potassium, magnesium, phosphorus and ribonucleic acid of Aerobacter aerogenes, growing in a chemostat. J. gen. Microbiol. 45, 547.

Herbert, D. (1958). Some principles of continuous culture. In Recent Progress in Microbiology, VIIth int. Congr. Microbiol., p. 381 .

Herbert, D., Phipps, P. J. \& Tempest, D. W. (1965). The chemostat: design and instrumentation. Lab. Practice r4, I I 50.

Postgate, J. R. \& Hunter, J. R. (1962). The survival of starved bacteria. J. gen. Microbiol. $29,233$. 
Postgate, J. R. \& Hunter, J. R. (1964). Accelerated death of Aerobacter aerogenes starved in the presence of growth-limiting substrates. J. gen. Microbiol. 34, 459.

Rouf, M. A. (I964). Spectrochemical analysis of inorganic elements in bacteria. J. Bact. 88, 1545.

Strange, R. E. \& Shon, M. (1964). Effects of thermal stress on viability and ribonucleic acid of Aerobacter aerogenes in aqueous suspension. J. gen. Microbiol. 34, 99.

SyKeS, J. \& TEMPEST, D. W. (1965). The effect of magnesium and of carbon limitation on the macromolecular organisation and metabolic activity of Pseudomonas sp., strain C-1 B. Biochim. biophys. Acta ro3, 93 .

TeMPEST, D. W. \& STRANGE, R. E. (I966). Variation in content and distribution of magnesium, and its influence on survival, in Aerobacter aerogenes grown in a chemostat. J. gen. Microbiol. 44, 273.

TemPest, D. W., Hunter, J. R. \& Sykes, J. (1965). Magnesium-limited growth of Aerobacter aerogenes in a chemostat. J. gen. Microbiol. 39, 355 .

Tempest, D. W., Dicks, J. W. \& HunTer, J. R. (1966). The interrelationship between potassium, magnesium and phosphorus in potassium-limited chemostat cultures of Aerobacter aerogenes. J. gen. Microbiol. 45, I35.

Tempest, D. W., Dicks, J. W. \& MeERs, J. L. (1967). Magnesium and the growth of Bacillus subtilis. Biochem. J. 102, 36P.

Webr, M. (1949). The influence of magnesium on cell division. 2. The effect of magnesium on the growth and cell division of various bacterial species in complex media. J. gen. Microbiol. 3, 4IO.

WeBв, M. (1966). The utilization of magnesium by certain Gram-positive and Gram-negative bacteria. J. gen. Microbiol. 43, 401 . 